\section{Fungicide Programs Affect 'Practical' Resistance Development in Cucurbit Powdery Mildew of Pumpkin}

\author{
Christian A. Wyenandt ${ }^{1,4}$, Nancy Maxwell ${ }^{2}$, and Daniel L. Ward ${ }^{3}$ \\ Rutgers University, Rutgers Agricultural Research and Extension Center, \\ 121 Northville Road, Bridgeton, NJ 08302
}

Additional index words. fungicide resistance management, Fungicide Resistance Action Committee, FRAC, Cucurbita pepo

Abstract. The effects of two pumpkin cultivars and five fungicide programs on cucurbit powdery mildew development and yield were evaluated in southern New Jersey from 2005 to 2007. Each year, five separate fungicide programs were applied to powdery mildewtolerant cv. Magic Lantern or powdery mildew-susceptible cv. Howden pumpkin. The five fungicide programs applied season-long (10 applications per program) included: 1) protectant fungicides only: manzate + sulfur [Fungicide Resistance Action Committee (FRAC) codes M3 + M2] alternated weekly with maneb + copper hydroxide (FRAC codes M3 + M1); 2) standard program: chlorothalonil + myclobutanil (FRAC codes M5 + 3) alternated with azoxystrobin (FRAC code 11); 3) intensive program: maneb + myclobutanil (FRAC codes M3 + 3) alternated with [famoxadone + cymoxanil] (FRAC codes 11 + 27); 4) FRAC code 3 weekly: chlorothalonil + myclobutanil (FRAC codes M5 + 3) alternated with myclobutanil (FRAC code 3); and 5) FRAC code 11 weekly: chlorothalonil + azoxystrobin (FRAC codes M5 +11 ) alternated with azoxystrobin (FRAC code 11). In each year, there were no significant interactions between the fungicide program and cultivar. In each year, area under disease progress curve values were highest when a FRAC code 11 fungicide was applied weekly compared with a FRAC code 11 fungicide applied in a weekly rotation with a FRAC code 3 fungicide or a FRAC code 3 fungicide applied weekly. Visual examination of leaves at the end of each production season revealed there were no significant differences in powdery mildew development on the top (adaxial) or bottom (abaxial) sides of leaves in untreated subplots. Powdery mildew development was lower on the bottom sides of leaves when a Fungicide Resistance Action Committee (FRAC) code 3 fungicide was applied weekly compared with a FRAC code 11 fungicide applied weekly or when a FRAC code 3 fungicide was rotated weekly with a FRAC code 11 fungicide in each year of the study. There were no significant differences in total number of harvested fruit, number of harvested orange fruit, average weight of orange fruit, or percentage of harvested orange fruit between fungicide programs in each year of the study. Results of this study, based on arcsine-transformed area under disease progress curve (AUDPC) values and top and bottom leaf surface ratings, suggest that the weekly use of the FRAC code 11 fungicide lead to the development of practical resistance in the field population of cucurbit powdery mildew. Rotating a FRAC code 11 and FRAC code 3 fungicide weekly resulted in lower AUDPC values and powdery mildew development on the bottom side of leaves in 2 of 3 years of this study. However, based on AUPDC values and leaf rating values, the level of control obtained with the high-risk FRAC code 3 fungicide was less during each consecutive year. The immediate erosion of control (i.e., qualitative resistance) as observed with the FRAC code 11 fungicide or the gradual decline of control (quantitative resistance) as observed with the FRAC code 3 fungicide over three growing seasons shows the importance of being able to detect and understand the mechanisms of practical resistance development. This understanding will allow appropriate fungicide control recommendations to be made in a timely (i.e., real-time) manner. Importantly, fungicide resistance is most likely to develop on the bottom side (abaxial) of pumpkin leaves when effective, low-risk (nonmobile) fungicides (FRAC code M numbers) are tank-mixed with high-risk fungicides in cucurbit powdery mildew control programs. Tank-mixing fungicides that have a high risk for resistance development with protectant fungicides that have a low risk for resistance development remains critically important when controlling cucurbit powdery mildew and reducing the potential for fungicide resistance development. This is the first report of cucurbit powdery mildew developing practical resistance to a FRAC code 11 and FRAC code 3 fungicide in New Jersey.

\footnotetext{
Received for publication 14 Feb. 2008. Accepted for publication 6 June 2008.

${ }^{1}$ Extension Specialist in Vegetable Pathology. ${ }^{2}$ Field Researcher IV.

${ }^{3}$ Extension Specialist in Pomology.

${ }^{4}$ To whom reprint requests should be addressed; e-mailwyenandt@aesop.rutgers.edu.
}

In the United States, pumpkin (Cucurbita реро) crops are grown primarily for wholesale processing and ornamental use. Pumpkin production in the United States increased $6.4 \%$ in 2005 from 2004 totaling 1.1 billion pounds (U.S. Department of Agriculture,
2006). In 2007,2500 acres were harvested in New Jersey, accounting for $\approx 5 \%$ of U.S. production (Crop profile for pumpkins in New Jersey, 2007). Although considered a minor vegetable crop based on the numbers of acres produced each year in New Jersey, pumpkin crops play a critical role in keeping small roadside farm markets operational during fall months through agritourism events such as fall festivals, grade school farm tours, and u-pick operations.

Powdery mildew [Podosphaera (sect. Sphaerotheca) xanthii (Castagne) U. Braun $\&$ N. Shishkoff (also known as Sphaerotheca fusca (Fr.) S. Blumer and S. fuliginea (Schlechtend.:Fr.) Pollacci] is an important disease of cucurbit crops throughout the United States (Zitter et al., 1996). The pathogen may overwinter on crop debris; however, in most years, the pathogen is wind-dispersed into northern regions from southern states each production season (Zitter et al., 1996). The pathogen typically infects older leaves and stems first causing premature loss of foliage resulting in a reduction in yield as the size and number of fruit decrease (Mossler and Nesheim, 2003; Zitter et al., 1996). Premature defoliation can also lead to sunscald injury resulting in unmarketable fruit. Stems infected by powdery mildew before harvest will prematurely turn brown and shrivel reducing the postharvest longevity of marketable fruit.

Control of cucurbit powdery mildew begins with preventing nutritional stress (Pernezny and Stall, 2005), planting tolerant or resistant varieties such as cvs. Magic Lantern, Magician, or Gold Bullion (McGrath and Davey, 2006) and preventive fungicide applications (Alexander and Waldenmaier, 1999; Fitzgerald et al., 2005; McGrath and Shishkoff, 1999; Shamiyeh et al., 1999). Pumpkin breeding lines and cultivars have been consistently evaluated for cucurbit powdery mildew resistance, and in recent years, new cultivars with powdery mildew tolerance have been released commercially (Epinat et al., 1992; James and Stevenson, 2003, 2004, 2005, 2006; Kooistra, 1968; McGrath and Shishkoff, 2001; O'Brien, 1994; O'Brien et al., 1988).

Preventive fungicides, particularly those that are systemic or translaminar, are able to suppress the disease on abaxial (underside or bottom) leaf surfaces where conditions are more favorable for powdery mildew development (McGrath, 2001a). Effective control of powdery mildew depends on the timing of spray applications, the fungicide(s) used to control the disease, the age of the leaves, the presence of pathogen on the top or bottom surfaces of leaves, and pumpkin cultivar (Everts, 1999a, 1999b, 2002; McGrath and Staniszewska, 1994; McGrath, 1996a, 2001b). Some newer fungicide chemistries for cucurbit powdery mildew control have modes of action that target fungal growth and development at specific metabolic site(s) (McGrath, 2001a, 2005). In general, the more specific a fungicide's mode of action, the higher potential there is for fungicide resistance 
development. This is especially important in cucurbit powdery mildew where resistance to certain fungicide chemistries has already been detected (McGrath, 2001a).

Resistance to systemic fungicides has been researched and documented (Huggenberger et al., 1984; Kendall, 1986; McGrath, 1996b; O'Brien et al., 1988; Ohtsuka et al., 1988; Peterson, 1973; Schroeder and Provvidenti, 1969). The first case of fungicide resistance development in the United States was reported in cucurbit powdery mildew to the fungicide, benomyl (Schroeder and Provvidenti, 1969). Since that time, resistance in cucurbit powdery mildew to other fungicides in FRAC code 1 have been reported (McGrath, 1996b). In the late 1990s, a new class of fungicide, known as the strobilurins (FRAC code 11), were commercially released for the control of cucurbit powdery mildew. Cucurbit powdery mildew resistance to strobilurin fungicides [quinone outside inhibitors (QoI), FRAC code 11] was first reported in the United States in 2002 (McGrath and Shishkoff, 2003). Managing fungicide resistance has been an important aspect of managing cucurbit powdery mildew (McGrath, 2001a; McGrath and Shishkoff, 2003). Additionally, management of fungicide resistance in cucurbit powdery mildew has been studied and techniques developed to directly or indirectly detect it under field conditions (Cohen et al., 2004; Cushman et al., 2007; McGrath and Shishkoff, 2001). When such indirect techniques are used to measure fungicide resistance development, terms such as "field" or "practical" resistance have been used to describe the observable loss of chemical control. Indirect observations of fungicide resistance development are extremely important and useful for disease management because the observations can be used to make or adjust current fungicide recommendations in specific states or geographic regions.

As a result of the importance of understanding and managing fungicide resistance, an industry-led group, known as the FRAC, was established in the early 1980s (Fungicide Resistance Action Committee, 2006). FRAC committees have been established throughout Europe, North and South America, and Japan to manage and monitor fungicide resistance development. In 2002, the NA-FRAC (North American Fungicide Resistance Action Committee) was established to 1) coordinate and identify resources for contact between government, universities, and the public on fungicide resistance management issues; 2) assist in the creation of new working codes in North America for other areas of chemistry as they are needed; and 3) serve as a spokesman for the industry's view on fungicide resistance management (Fungicide Resistance Action Committee, 2006).

Each year, the FRAC committee updates and publishes a list of FRAC codes, which contain most of the fungicides and fungicide chemistries in which mode of action and resistance risk are known (Fungicide Resistance Action Committee, 2006). As of 2006, there were 43 numbered and three-lettered FRAC codes for the $\approx 93$ listed chemical groups and 181 common names of fungicides (Fungicide Resistance Action Committee, 2006). Accordingly, fungicides listed within a given FRAC code may share a similar mode of action and, therefore, may have: 1) similar risks for resistance development; 2) similar use patterns on single or multiple crops; and 3 ) exhibit the potential for cross-resistance development. Of the 43 numbered and three-lettered FRAC group codes in 2006, fungicide resistance was common, known, reported, or described in $54 \%$ of the FRAC groups and resistance management recommended or required for $52 \%$ of the groups.

In recent years, fungicide resistance has been detected in important diseases of vegetable crops grown in the eastern United States, including the mid-Atlantic region (Louws and Driver, 2001, 2005; Norton, 1982; Van der Meer et al., 1978). Unfortunately, some growers become concerned about managing resistance only after it has developed, although it is more important to recognize the primary goal of resistance management is to delay its development rather than to manage resistant strains (McGrath, 2001a). The large number of fungicide chemistries available and the differences in modes of action can make it very difficult for vegetable growers to develop and follow fungicide resistance management programs on their farms. In many cases, fungicides within a given FRAC code are listed for the control of the same pathogen, which can lead to confusion by vegetable producers when it comes to developing a seasonal fungicide application program for specific diseases. For example, gummy stem blight caused by Didymella bryoniae (Auersw.) Rehm [syn. Mycosphaerella melonis (Pass.) Chui \& J.C. Walker] is an important disease in cucurbit crops in the United States. In the mid-Atlantic region, resistance in the gummy stem blight fungus to azoxystrobin has been documented (Everts, 1999b) and FRAC code 11 fungicide chemistries such as azoxystrobin and pyraclostrobin are currently recommended control options, although both fungicides have a high risk for fungicide resistance development. Although both chemistries are still effective in some areas in the mid-Atlantic region, it is very important for growers who have resistance on their farm to know which fungicides belong to FRAC code 11 so that these fungicides are used in tank mixes and/or in rotations with other fungicide chemistries (i.e., FRAC codes) and not used in alternation with each other.

Because development of fungicide resistance in a production field can be difficult to measure without specific laboratory methods, a cucurbit grower could be unknowingly selecting for a resistant fungal population through the improper use of certain fungicide chemistries (McGrath, 2001a). The successful management of fungicide resistance in highly mobile pathogens such as cucurbit powdery mildew may require regional coop- eration. Otherwise, growers using high-risk fungicides exclusively may select resistant strains and thereby reduce the efforts of growers using a resistance management program (McGrath, 2001a).

The objectives of this study were to evaluate the effects of cultivar resistance and five different fungicide programs on fungicide resistance development in cucurbit powdery mildew in pumpkin production.

\section{Materials and Methods}

From 2005 to 2007, controlled studies were conducted in a field (Aura sandy loam, $\mathrm{pH}=6.4)$ at the Rutgers Agricultural Research and Extension Center in Bridgeton, NJ. Five weekly fungicide programs were done seasonlong (10 total applications per program) in each year of the study. The five fungicide programs consisted of 1) protectant fungicides only: $2.24 \mathrm{~kg} \cdot \mathrm{ha}^{-1}$ manzate (Manzate 75DF; Griffin LLC, Valdosta, GA) + $2.24 \mathrm{~kg} \cdot \mathrm{ha}^{-1}$ sulfur (Microthiol Disperss; Cerexagri, Inc., King of Prussia, PA) (FRAC codes M3 + M2) alternated weekly with $2.24 \mathrm{~kg} \cdot \mathrm{ha}^{-1}$ maneb (Maneb 80WP; Cerexagri, Inc.) $+1.51 \mathrm{~L} \cdot \mathrm{ha}^{-1}$ copper hydroxide (Champ 2F; NuFarm Americas, Burr Ridge, IL) (FRAC codes M3 + M1); 2) standard program: $3.5 \mathrm{~L} \cdot \mathrm{ha}^{-1}$ chlorothalonil (Bravo WeatherStik; Syngenta Crop Protection, Greensboro, NC) $+0.35 \mathrm{~kg} \cdot \mathrm{ha}^{-1}$ myclobutanil (Nova 40WP; Dow AgroSciences, Indianapolis, IN) (FRAC codes M5 + 3) alternated with $0.35 \mathrm{~kg} \cdot \mathrm{ha}^{-1}$ azoxystrobin (Amistar; Syngenta Crop Protection, Greensboro, NC) (FRAC code 11); 3) intensive program: 2.24 $\mathrm{kg} \cdot \mathrm{ha}^{-1}$ maneb $+0.35 \mathrm{~kg} \cdot \mathrm{ha}^{-1}$ myclobutanil (FRAC codes M3 + 3) alternated with 0.56 $\mathrm{kg} \cdot \mathrm{ha}^{-1}$ [famoxadone + cymoxanil] (Tanos 50WDG; E.I. Du Pont Nemours and Company, Wilmington, DE) (FRAC codes $11+$ 27); 4) FRAC code 3 weekly: $3.5 \mathrm{~L} \cdot \mathrm{ha}^{-1}$ chlorothalonil $+0.35 \mathrm{~kg} \cdot \mathrm{ha}^{-1}$ myclobutanil (FRAC code M5 + 3) alternated with 0.35 $\mathrm{kg} \cdot \mathrm{ha}^{-1}$ myclobutanil (FRAC code 3 ); and 5) FRAC code 11 weekly: $3.5 \mathrm{~L} \cdot \mathrm{ha}^{-1}$ chlorothalonil $+0.35 \mathrm{~kg} \cdot \mathrm{ha}^{-1}$ azoxystrobin (FRAC codes M5 + 11) alternated with $0.35 \mathrm{~kg} \cdot \mathrm{ha}^{-1}$ azoxystrobin (FRAC code 11).

In each year, five strips (each $24 \mathrm{~m}$ wide $\times$ $46 \mathrm{~m}$ long) were set up for fungicide programs. Between each strip, 4.6-m-wide wind breaks were established by seeding sorghumsudangrass hybrid 'Green Grazer V' (Seedway, Hall, NY) at $67.2 \mathrm{~kg} \cdot \mathrm{ha}^{-1}$ on $20 \mathrm{Apr}$. 2005, 3 May 2006, and 25 May 2007 to prevent drift between fungicide programs. The same seeding rate was used to create a 9.1-m-wide wind break on the southwest edge of the field to reduce wind speed and reduce potential fungicide drift.

On 22 June 2005 and 2006 and 19 June 2007, each strip was split into subplots and powdery mildew-tolerant cv. Magic Lantern or powdery mildew-susceptible cv. Howden (Harris Moran Seed Company, Modesto, CA) was seeded in separate alternating rows on 3.1-m centers for a total of four rows (two per cultivar) per strip. Pumpkins in each row 
were seeded on 0.6-m centers (two seeds/ hill). Within each strip, subsubplots consisted of five treated (fungicide application) and five untreated plots (no fungicide application). The first subsubplot in each strip was randomly assigned and the succeeding subsubplots alternated between fungicide and no fungicide application. Each fungicide subsubplot was $7.6 \mathrm{~m}$ long with a $3.1-\mathrm{m}$ in-row space between each subsubplot. On 23 June 2005 and 2006 and 20 June 2007, the herbicide containing ethalfluralin and clomazone (Strategy; Loveland Products, Greeley, CO) was applied preemergence at $5.8 \mathrm{~L} \cdot \mathrm{ha}^{-1}$ and followed by overhead irrigation for $2 \mathrm{~h}$ applying $\approx 1$ inch of water for weed control. Standard fertility, insect control, and irrigation schedules were done according to local commercial recommendations. Fungicide applications for powdery mildew control were initiated on 15 July 2005, 25 July 2006, and 24 July 2007 and repeated weekly (every 5 to $10 \mathrm{~d}$ ) until harvest for a total of 10 applications per fungicide program per season. The first application in each year was done using a $\mathrm{CO}_{2}$ tractor-mounted sprayer with a $1.5-\mathrm{m}$-wide boom with three hollowcone (D4-25, disc core) drop nozzles (one on top and one on each side of the plant at a $45^{\circ}$ angle) operated at $385 \mathrm{~L} \cdot \mathrm{ha}^{-1}$ at $44 \mathrm{psi}$. All remaining fungicide applications were done with a 3.1-m-wide tractor-mounted boom $\mathrm{CO}_{2}$ sprayer (R\&D Sprayers, Opelousa, LA) in a volume of water equivalent to 413 $\mathrm{L} \cdot \mathrm{ha}^{-1}$ and 58 psi using 8003VS flat-fan nozzles (Spraying Systems Co., Carol Stream, IL) spaced on $0.51-\mathrm{m}$ centers on the boom.

Maintenance sprays for downy mildew [Pseudoperonospora cubensis (Berk \& M.A. Curtis) Rostovzev] control were done on 23 July, 5 Aug., and 20 Aug. 2005 by applying 7.0 L $\cdot \mathrm{ha}^{-1}$ phosphite (FRAC code 33; NuFarm Chemicals) and on 28 July and 12 Aug. 2005 by applying $2.24 \mathrm{~kg} \cdot \mathrm{ha}^{-1}$ [zoxamide + mancozeb] (FRAC codes $22+$ M3). Similarly, in 2006, on 27 July, 8 Aug., 15 Aug., 22 Aug., 29 Aug., and 9 Sept. 2006, $2.24 \mathrm{~kg} \cdot \mathrm{ha}^{-1}$ [zoxamide + mancozeb] +5.84 $\mathrm{L} \cdot \mathrm{ha}^{-1}$ phosphite were applied to suppress downy mildew development. Maintenance sprays for downy mildew control were not necessary in 2007.

On 27 July 2005, 25 July 2006, and 25 July 2007 in each year, starting with the first fungicide application date and for each week after (10 weeks total), entire subsubplots were visually scored for powdery mildew development. Each week, pumpkin foliage from each subsubplot was visually rated on a scale of 0.0 to 1.0 (in which $0.0=$ none, $1.0=$ $100 \%$ severity) for symptoms of powdery mildew development (i.e., combined percentage of top and bottom of leaf surfaces with powdery mildew) to develop disease progress curves for each subsubplot. Arcsine-transformed AUDPC values for powdery mildew development were calculated for each year and statistically analyzed to determine if significant differences existed between fungicide programs.
In addition to the weekly foliar ratings, the percentage of upper and lower leaf surfaces with powdery mildew symptoms was estimated at harvest in each year. On 3 Oct. 2005, 2 Oct. 2006 and 26 Sept. 2007, the top and bottom leaf surface of five randomly selected individual mature leaves from each subsubplot were visually rated on a scale of 0.0 to 1.0 (in which $0.0=$ none, $1.0=100 \%$ ) for symptoms of powdery mildew development (i.e., percentage of top or bottom of leaf surfaces with symptoms of powdery mildew) and statistically analyzed to determine if significant differences existed between fungicide programs and leaf surfaces.

All fruit were harvested, graded, and weighed on 17 Oct. 2005, 10 Oct. 2006, and 3 Oct. 2007 to determine marketable total weight of harvested fruit (green + orange), weight of orange fruit, average fruit size (i.e., weight) of orange fruit, percentage orange fruit, and the percentage of fruit with healthy green stems.

Data from each year were analyzed separately because disease pressure was substantively different in each year of the study and visual ratings of powdery mildew were recorded on different dates each year. For the AUDPC and harvest variables, the data were analyzed as a strip-split-split-plot design with fungicide program as the whole-plot factor, cultivar as the subplot factor, and fungicide application as the subsubplot factor (Littell et al., 2006). For powdery mildew ratings at harvest, the addition of the leaf surface (top versus bottom) factor to the model resulted in a strip-split-split-split-plot design. The MIXED procedure of the SAS System (version 9.13; SAS Institute, Cary, NC) was used to fit a mixed effects analysis of variance to test for main effects of cultivar, fungicide application, and surface as well as interaction effects among all treatment factors. Significant interactions were further investigated using the SLICE option to per- form tests of simple main effects within each level of the interacting factor. Mean separation was conducted using Tukey's honestly significant difference test $(\alpha=0.05)$. Model adequacy was assessed using plots of standardized residuals.

\section{Results and Discussion}

Effect of cultivar on powdery mildew development in 2005 to 2007. The percentage of leaves with powdery mildew in unsprayed plots was greater than $80 \%$ at the final rating date in both cultivars in each year of the study (Figs. 1-6). Cultivar had no effect on powdery mildew development in $2005(P=0.73)$ (Table 1). However, in 2006 and 2007, AUDPC value was higher in 'Howden' compared with 'Magic Lantern' (1867 versus $1516, P=0.0002)$ and (2857 versus 2213 , $P<0.001)$. In each year, there were no significant cultivar $\times$ fungicide application or fungicide program $\times$ cultivar $\times$ fungicide application interactions.

Effect of fungicide program (FRAC code) on powdery mildew development from 2005 to 2007. Powdery mildew was first detected in both cultivars on 27 Aug. 2005, 17 Aug. 2006, and 25 July 2007 (data not shown). In each year, powdery mildew development was reduced when fungicides were applied (Figs. 1-6). Based on AUDPC value, there were no significant differences in powdery mildew development in unsprayed subplots during each year of the study (Table 1).

In 2005, AUDPC value for powdery mildew development was lower when a FRAC code 3 fungicide was applied weekly compared with the standard program (FRAC code 11 fungicide rotated weekly with a FRAC code 3 fungicide) and highest when a FRAC code 11 fungicide was applied weekly (Table 1). The AUDPC value for the fungicide program that contained protectant fungicides only (FRAC code M) were

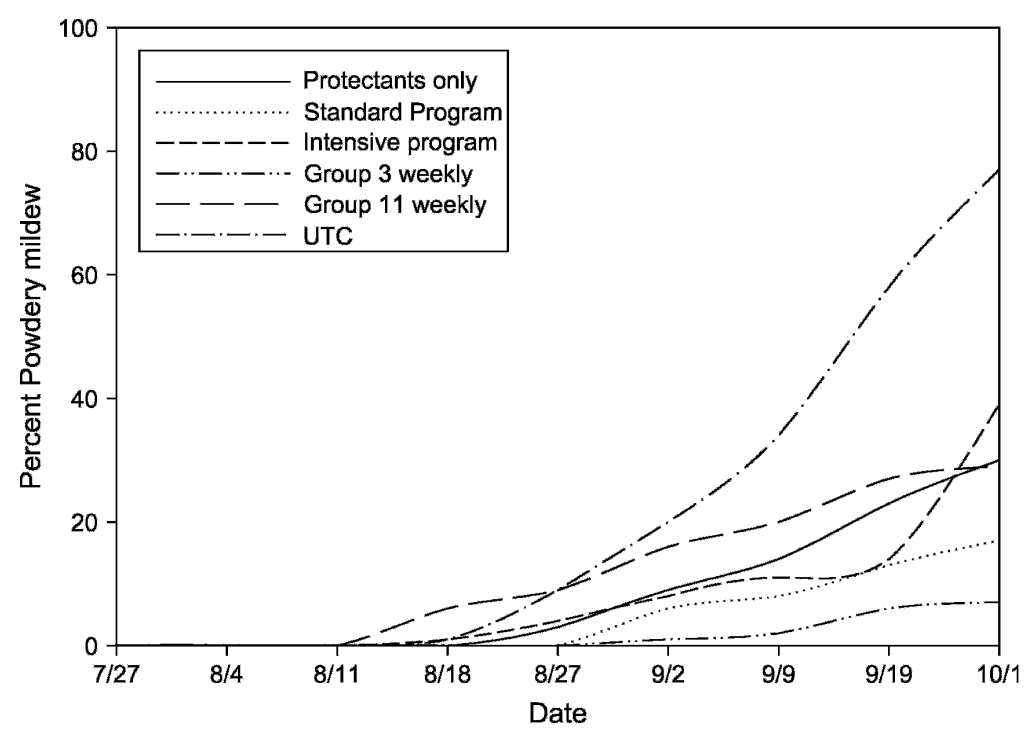

Fig. 1. Disease progress curves for the development of powdery mildew under six different fungicide programs in pumpkin cv. Howden in 2005. 


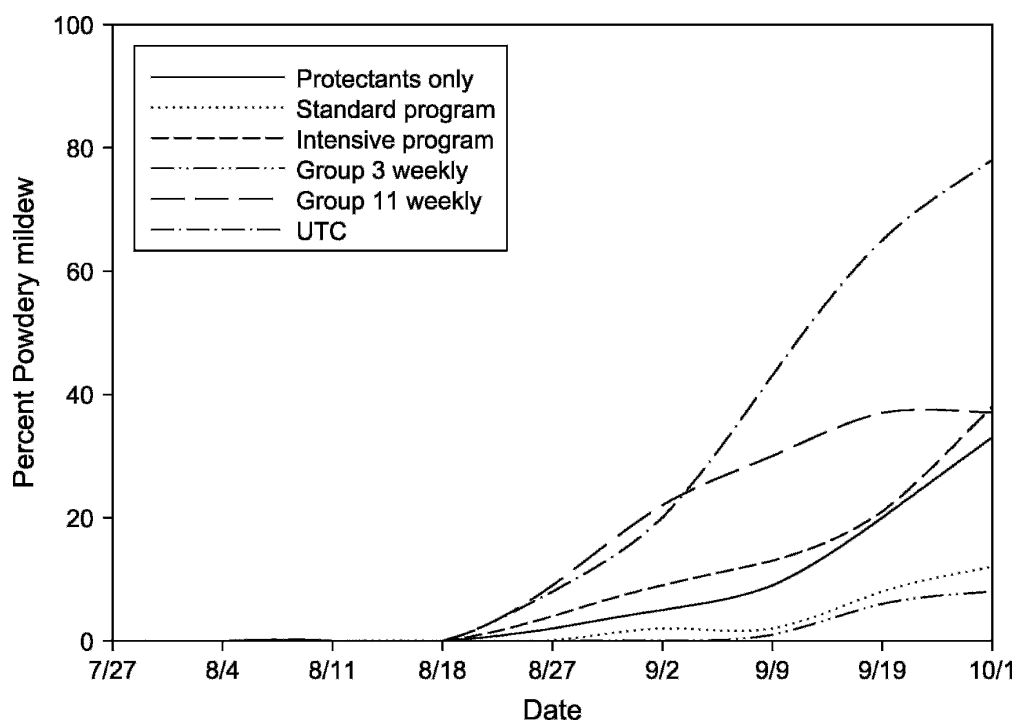

Fig. 2. Disease progress curves for the development of powdery mildew under six different fungicide programs in pumpkin cv. Magic Lantern in 2005.

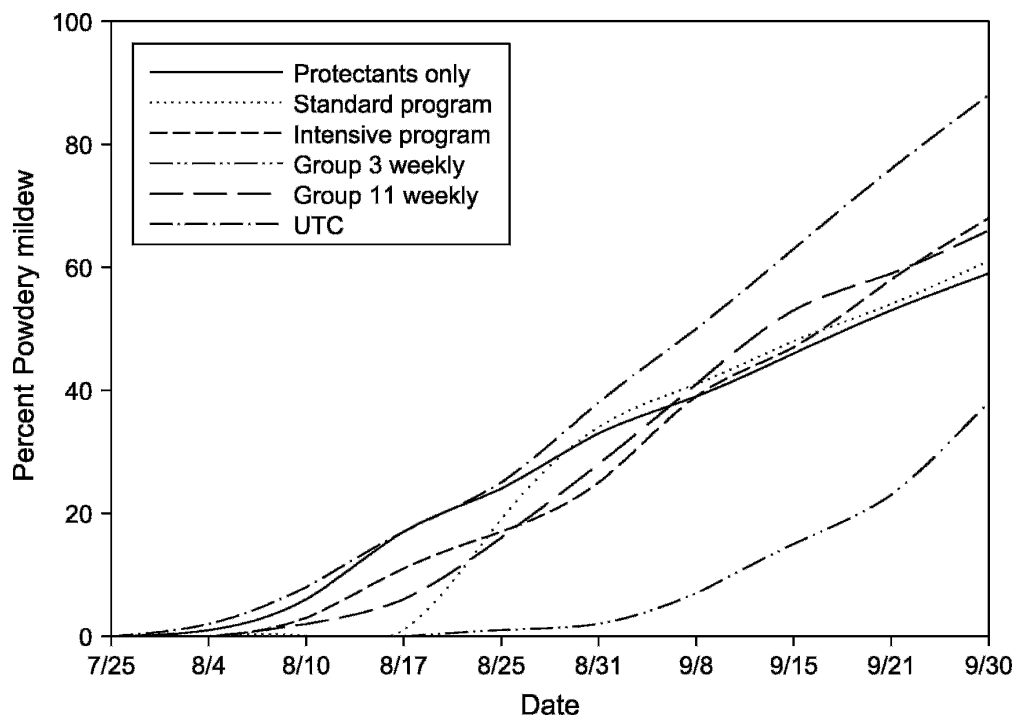

Fig. 3. Disease progress curves for the development of powdery mildew under six different fungicide programs in pumpkin cv. Howden in 2006.

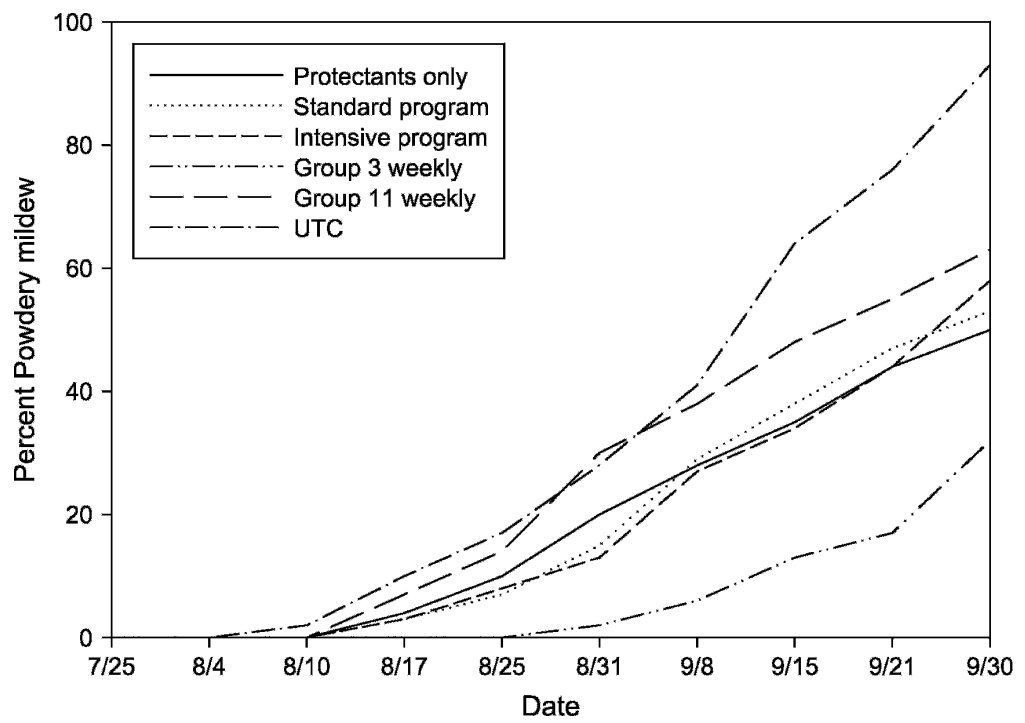

Fig. 4. Disease progress curves for the development of powdery mildew under six different fungicide programs in pumpkin cv. Magic Lantern in 2006. lower compared with a FRAC code 11 fungicide applied weekly but higher compared with the standard program in 2005 (Table 1).

In 2006, AUDPC value for powdery mildew development was lowest when a FRAC code 3 fungicide was applied weekly (Table 1). Although not statistically different from the protectant only, standard, or intensive program, the AUDPC value was numerically highest when a FRAC code 11 fungicide was applied weekly (Table 1).

In 2007, AUDPC values were significantly higher when a FRAC code 11 fungicide was applied weekly compared with a FRAC code 3 fungicide applied weekly. There were no differences in AUDPC values between the FRAC code 3 weekly, standard, or protectant only programs in 2007 (Table 1).

In each year of the study, AUDPC values were higher when FRAC code 11 fungicide was applied weekly compared with a FRAC code 3 fungicide applied weekly or when a FRAC code 11 fungicide was rotated weekly with a FRAC code 3 fungicide (standard program). This suggests that resistance developed to the FRAC code 11 fungicide during each production season and, at least in part, was the reason for reduced control when the FRAC code 11 fungicide was rotated weekly with the FRAC code 3 fungicide in the standard program during the first 2 years of the study. Reduced control is often the first indication resistance has developed (McGrath and Shishkoff, 2003). Resistance to FRAC code 11 (QoI) fungicides in powdery mildew populations were reported in Europe and Japan after 2 years of commercial use (McGrath, 2001a). Resistance was determined to arise independently at isolated locations rather than as the result of clonal spread (McGrath, 2001a). Resistance developed in some crops, although growers limited the number of QoI fungicides and applied the fungicides in alternation with fungicides in other chemical codes as recommended (McGrath, 2001a).

The first detection of QoI resistance in cucurbit powdery mildew in the United States was in 2002 when efficacy was poor in several university research fields and commercial crops throughout the United States and where strobilurin efficacy was reported to decline dramatically after only the second application in a research trial in New York state (McGrath and Shishkoff, 2003). QoI resistance is conferred by a single amino acid mutation, referred to as G143A mutation, in which as a result of the mutation, there is a single amino acid shift at position 143 from glycine to alanine in the cytochrome $\mathrm{b}$ protein involved in fungal respiration (Baumler, 2004). The G143A mutation is the most effective and widespread mode of QoI resistance (Baumler, 2004; Kuck and Mehl, 2003). Strobilurin (QoI) resistance is known to be qualitative in nature; thus, once resistance has developed, further use of the fungicide will no longer be effective.

Effect of fungicide program on the development of powdery mildew on the top 


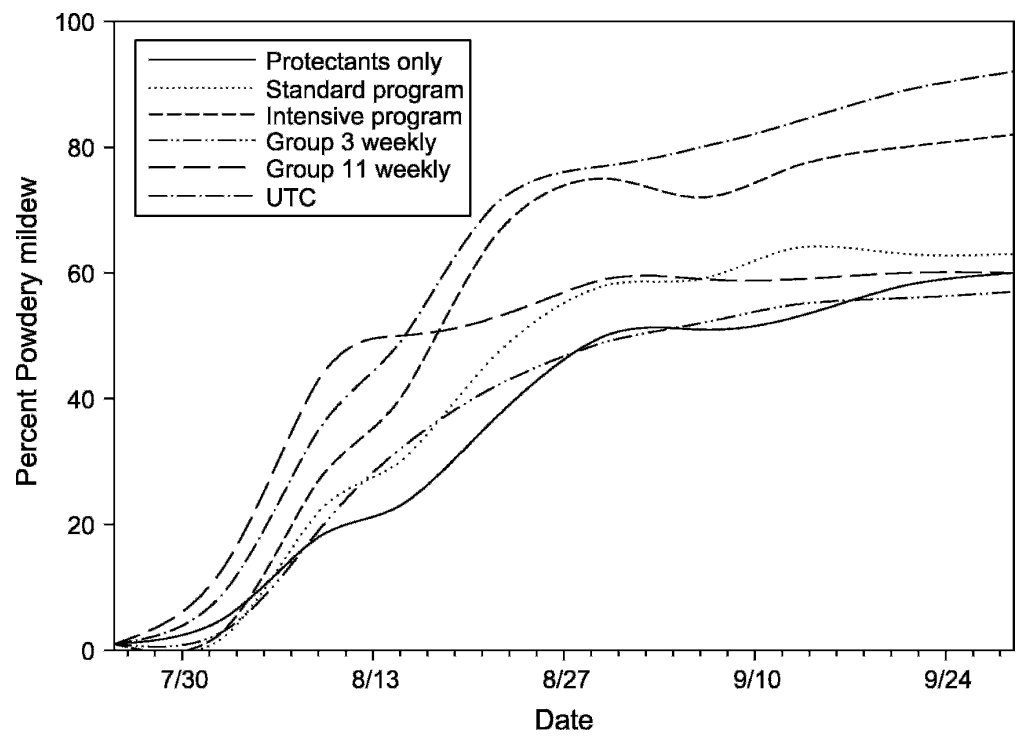

Fig. 5. Disease progress curves for the development of powdery mildew under six different fungicide programs in pumpkin cv. Howden in 2007.

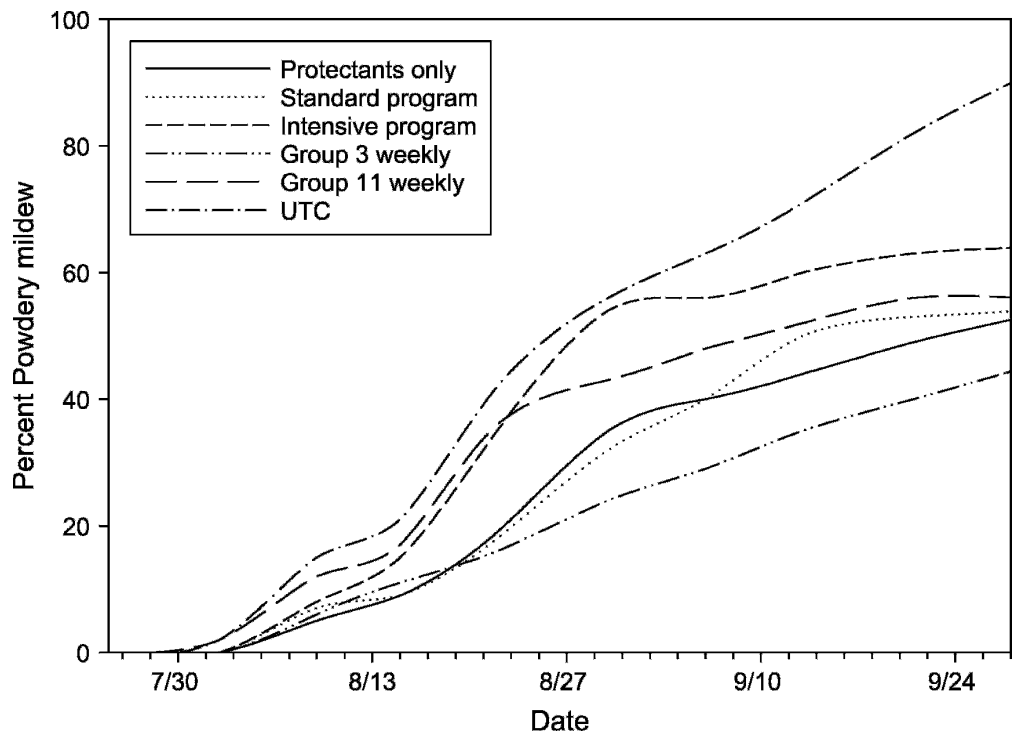

Fig. 6. Disease progress curves for the development of powdery mildew under six different fungicide programs in pumpkin cv. Magic Lantern in 2007.

and bottom leaf surfaces of powdery mildewsusceptible $c v$. Howden and powdery mildew-tolerant $c v$. Magic Lantern from 2005 to 2007. In each year, there were no significant differences in powdery mildew development between the top or bottom surfaces of leaves when no fungicides were applied season long (Table 2). In 2005 and 2007, there were no significant differences in powdery mildew development on the top leaf surface between fungicide programs (Table 2). In 2006, powdery mildew development was higher on the top sides of leaves in the intensive program compared with all other fungicide programs (Table 2).

In 2005 , powdery mildew development was highest on the bottom surface of leaves when a FRAC code 11 fungicide was applied weekly and lowest when a FRAC code 3 fungicide was applied weekly compared with all other fungicide programs. Comparatively, powdery mildew was significantly higher in the standard program compared with the FRAC code 3 program and significantly lower compared with the FRAC code 11 program suggesting that the FRAC code 11 fungicide in the standard program was resulting in reduced control on the bottom surfaces of leaves (Table 2).

In 2006, powdery mildew was highest on the bottom surface of leaves treated with a FRAC code 11 fungicide weekly, but not significantly different from the protectant program. Like 2005, powdery mildew development was significantly higher in the standard program compared with the FRAC code 3 program and significantly lower compared with the FRAC code 11 program suggesting that the FRAC code 11 fungicide in the standard program was resulting in reduced control on the bottom surfaces of leaves (Table 2).

In 2007, powdery mildew was highest on the bottom surface of leaves in the protectants only, intensive, and FRAC code 11 fungicide program. Like 2005 and 2006, powdery mildew development was lowest when a FRAC code 3 fungicide was applied weekly (Table 2). In 2007, there was no significant difference between the FRAC code 11 weekly and standard program suggesting that although the FRAC code 3 program was significantly lower than all other treatments when used alone, the FRAC code 3 fungicide in the standard program was most likely beginning to lose efficacy against powdery mildew (Table 2).

Control of powdery mildew on the bottom of pumpkin leaves with "mobile" fungicides such as those in FRAC code 3 and 11 should be considerably better than control with fungicides that have protectant, nonmobile properties if fungicide resistance has not developed. In each year, powdery mildew development was highest on the bottom surface of leaves when a mobile FRAC code 11 fungicide was applied weekly and lowest when a mobile FRAC code 3 fungicide was applied weekly. Results based on leaf ratings suggest that cucurbit powdery mildew developed practical resistance to the FRAC code 11 fungicide in all 3 years of the study and that by Year 3 of the study, the efficacy of the FRAC code 3 fungicide was reduced.

In each year, a FRAC code M (protectant) fungicide and/or a combination of protectant fungicides tank-mixed with high-risk fungicides were used in each program. Percent powdery mildew development on top surfaces of leaves in both years ranged from an expected $1 \%$ to $19 \%$ depending on fungicide program. Results of this study and as suggested by McGrath and Shishkoff (2001) confirm that fungicide-resistant powdery mildew populations may develop on the bottom surface of leaves when effective, protectant (FRAC code M) fungicides are used in season-long control programs in combination or rotation with high-risk mobile fungicides.

Effect of fungicide program on total number of harvested fruit, harvested orange fruit, weight of orange fruit, average weight of orange fruit, percentage orange fruit, and percentage of fruit with good stems in 2005 to 2007. In 2005, there were no significant differences in total number of harvested fruit, number of orange fruit, weight of total orange fruit, average weight of orange fruit, and percentage orange fruit between fungicide programs (Table 3). In 2005, there was a significant interaction between cultivar and fungicide application (FA) for total number of harvested orange fruit $(P=0.03)$, total weight of harvested orange fruit $(P=0.007)$, and the percentage of orange fruit $(P=0.04)$ (Table 3). In 2005, with the exception of total number of orange fruit in unsprayed (no fungicide) plots, total number and weight of harvested orange fruit and percentage of orange fruit were significantly higher for cv. Magic Lantern compared with cv. Howden 
Table 1. Arcsine-transformed area under disease progress curve (AUDPC) values for cucurbit powdery mildew development on pumpkin cvs. Howden and Magic Lantern by year, fungicide program, and fungicide application (sprayed or unsprayed).

\begin{tabular}{|c|c|c|c|c|c|c|}
\hline \multirow[b]{3}{*}{ Fungicide program } & \multicolumn{6}{|c|}{ AUDPC values } \\
\hline & \multicolumn{2}{|c|}{2005} & \multicolumn{2}{|c|}{2006} & \multicolumn{2}{|c|}{2007} \\
\hline & Unsprayed & Sprayed & Unsprayed & Sprayed & Unsprayed & $\overline{\text { Sprayed }}$ \\
\hline Protectants only & 1,105 & $655 b^{z}$ & 1,940 & $1,554 \mathrm{a}$ & 2,747 & $1,989 \mathrm{c}$ \\
\hline Standard program & 1,239 & $413 \mathrm{c}$ & 2,177 & $1,503 \mathrm{a}$ & 2,726 & $2,110 \mathrm{bc}$ \\
\hline Intensive program & - & - & 2,036 & $1,472 \mathrm{a}$ & 2,943 & $2,567 \mathrm{a}$ \\
\hline FRAC group 3 weekly & 1,219 & $242 \mathrm{~d}$ & 1,973 & $680 \mathrm{~b}$ & 2,881 & $1,914 \mathrm{c}$ \\
\hline FRAC group 11 weekly & 1,243 & $933 \mathrm{a}$ & 1,966 & $1,615 \mathrm{a}$ & 3,116 & $2,352 \mathrm{ab}$ \\
\hline$P$ value & NS & $<0.001$ & NS & $<0.0001$ & NS & $<0.0001$ \\
\hline Analysis of variance & \multicolumn{2}{|c|}{2005} & \multicolumn{2}{|c|}{2006} & \multicolumn{2}{|c|}{2007} \\
\hline Fungicide program (FP) & \multicolumn{2}{|c|}{0.0006} & \multicolumn{2}{|c|}{0.0024} & \multicolumn{2}{|c|}{$<0.0001$} \\
\hline Cultivar (CV) & \multicolumn{2}{|c|}{0.7286} & \multicolumn{2}{|c|}{0.0002} & \multicolumn{2}{|c|}{$<0.0001$} \\
\hline $\mathrm{FP} \times \mathrm{CV}$ & \multicolumn{2}{|c|}{0.0988} & \multicolumn{2}{|c|}{0.5886} & \multicolumn{2}{|c|}{0.1669} \\
\hline Fungicide application (FA) & \multicolumn{2}{|c|}{$<0.0001$} & \multicolumn{2}{|c|}{$<0.0001$} & \multicolumn{2}{|c|}{$<0.0001$} \\
\hline $\mathrm{FP} \times \mathrm{FA}$ & \multicolumn{2}{|c|}{$<0.0001$} & \multicolumn{2}{|c|}{$<0.0001$} & \multicolumn{2}{|c|}{$<0.0001$} \\
\hline $\mathrm{CV} \times \mathrm{FA}$ & \multicolumn{2}{|c|}{0.1142} & \multicolumn{2}{|c|}{0.35} & \multicolumn{2}{|c|}{0.5327} \\
\hline$\underline{\mathrm{FP}} \times \mathrm{CV} \times \mathrm{FA}$ & \multicolumn{2}{|c|}{0.9943} & \multicolumn{2}{|c|}{0.5644} & \multicolumn{2}{|c|}{0.1828} \\
\hline
\end{tabular}

${ }^{\mathrm{z}}$ Means within a column with letters in common are not significantly different according to Tukey's honestly significant difference test $(\alpha=0.05)$.

${ }^{\text {Ns Nonsignificant. }}$

Table 2. Mean percentage of cucurbit powdery mildew severity at harvest on pumpkin cvs. Howden and Magic Lantern by year, fungicide program, fungicide application, and leaf surface [top (adaxial) or bottom (abaxial)].

\begin{tabular}{|c|c|c|c|c|}
\hline \multirow[b]{3}{*}{ Fungicide program } & \multicolumn{4}{|c|}{$2005^{z}$} \\
\hline & \multicolumn{2}{|c|}{ Unsprayed } & \multicolumn{2}{|c|}{ Sprayed } \\
\hline & Top & Bottom & Top & Bottom \\
\hline Protectants only & 67 & 48 & 15 & $43 b^{y}$ \\
\hline Standard program & 56 & 48 & 12 & $33 \mathrm{~b}$ \\
\hline FRAC group 3 weekly & 64 & 34 & 2 & $3 \mathrm{c}$ \\
\hline FRAC group 11 weekly & 64 & 67 & 19 & $79 \mathrm{a}$ \\
\hline \multirow[t]{3}{*}{$P$ value } & NS & NS & NS & $<0.001$ \\
\hline & \multicolumn{4}{|c|}{2006} \\
\hline & \multicolumn{2}{|c|}{ Unsprayed } & \multicolumn{2}{|c|}{ Sprayed } \\
\hline Fungicide program & Top & $\overline{\text { Bottom }}$ & Top & Bottom \\
\hline Protectants only & 82 & 93 & $8 \mathrm{a}$ & $93 \mathrm{a}$ \\
\hline Standard program & 92 & 92 & $5 \mathrm{a}$ & $72 \mathrm{~b}$ \\
\hline Intensive program & 93 & 95 & $17 \mathrm{~b}$ & $64 \mathrm{~b}$ \\
\hline FRAC group 3 weekly & 94 & 95 & $1 \mathrm{a}$ & $31 \mathrm{c}$ \\
\hline FRAC group 11 weekly & 86 & 92 & $4 \mathrm{a}$ & 94 a \\
\hline \multirow[t]{3}{*}{$P$ value } & NS & NS & $<0.01$ & $<0.0001$ \\
\hline & \multicolumn{4}{|c|}{2007} \\
\hline & \multicolumn{2}{|c|}{ Unsprayed } & \multicolumn{2}{|c|}{ Sprayed } \\
\hline Fungicide program & Top & Bottom & Top & Bottom \\
\hline Protectants only & 51 & 90 & 1 & $89 \mathrm{a}$ \\
\hline Standard program & 48 & 81 & 3 & $72 \mathrm{~b}$ \\
\hline Intensive program & 47 & 73 & 11 & $76 \mathrm{ab}$ \\
\hline FRAC group 3 weekly & 50 & 68 & 2 & $48 \mathrm{c}$ \\
\hline FRAC group 11 weekly & 50 & 73 & 2 & $83 \mathrm{ab}$ \\
\hline$P$ value & NS & NS & NS & $<0.0001$ \\
\hline Analysis of variance & & 2005 & 2006 & 2007 \\
\hline Fungicide program (FP) & & 0.0594 & 0.0052 & 0.0219 \\
\hline Cultivar (CV) & & 0.6411 & 0.6663 & 0.1252 \\
\hline $\mathrm{FP} \times \mathrm{CV}$ & & 0.9319 & 0.6666 & 0.2568 \\
\hline Surface & & 0.1718 & $<0.0001$ & $<0.0001$ \\
\hline $\mathrm{FP} \times$ surface & & 0.0009 & $<0.0001$ & $<0.0001$ \\
\hline $\mathrm{CV} \times$ surface & & 0.4211 & 0.358 & 0.2105 \\
\hline $\mathrm{FP} \times \mathrm{CV} \times$ surface & & 0.0236 & 0.8999 & 0.9344 \\
\hline Fungicide application (FA) & & $<0.0001$ & $<0.0001$ & $<0.0001$ \\
\hline $\mathrm{FP} \times \mathrm{FA}$ & & 0.0004 & $<.0001$ & 0.0087 \\
\hline $\mathrm{CV} \times \mathrm{FA}$ & & 0.2005 & 0.0053 & 0.9798 \\
\hline $\mathrm{FP} \times \mathrm{CV} \times \mathrm{FA}$ & & 0.041 & 0.1125 & 0.3215 \\
\hline FA $\times$ surface & & $<0.0001$ & $<0.0001$ & $<0.0001$ \\
\hline $\mathrm{FP} \times \mathrm{FA} \times$ surface & & 0.0286 & $<0.0001$ & 0.0355 \\
\hline $\mathrm{CV} \times \mathrm{FA} \times$ surface & & 0.5033 & 0.7936 & 0.5753 \\
\hline $\mathrm{FP} \times \mathrm{CV} \times \mathrm{FA} \times$ surface & & 0.5695 & 0.2434 & 0.966 \\
\hline
\end{tabular}

${ }^{\mathrm{z}}$ Intensive program is not included in 2005 as a result of destruction of the plot by rain.

${ }^{\mathrm{y}}$ Means within a column with letters in common are not significantly different according to Tukey's honestly significant difference test $(\alpha=0.05)$.

Ns Nonsignificant.
(Table 4). When comparing the percentage of good stems in sprayed and unsprayed subplots in 2005, there was a significant interaction effect between fungicide program (FP) and FA $(P=0.0101)$ because FP increased the percentage of good stems in the standard, intensive, FRAC code 3, and FRAC code 11 weekly programs $(P<0.0001, P=0.0003$, $P<0.0001$, and $P<0.0001$, respectively) but not in the protectant only program $(P=$ 0.7187 ) (Table 3 ). For sprayed subplots in 2005 , the percentage of good stems was highest when a FRAC code 3 fungicide was applied weekly, followed by standard, protectant only, FRAC code 11 weekly, and intensive programs (Table 3 ).

In 2006, there were no significant differences in total number of harvested fruit, number of orange fruit, weight of orange fruit, average weight of orange fruit, percentage of orange fruit, and percent good stems among fungicide programs (Table 3 ).

In 2007 , there were no significant differences in total number of harvested fruit, number of orange fruit, percentage of orange fruit, and percentage good stems among fungicide programs (Table 3). The FRAC code 3 weekly program had significantly higher total weight of orange fruit than the protectant only and the standard program, but not the intensive or the FRAC code 11 weekly program (Table 3). In 2007, there was a significant fungicide program $\times$ fungicide application interaction (Table 3). In 2007, there was no significant difference in weight of orange fruit in cv. Howden across fungicide programs (Table 5). However, in cv. Magic Lantern, weight of orange fruit was highest when a FRAC code 3 or 11 fungicide was applied weekly, followed by the intensive and protectant weekly, and lowest when a FRAC code 3 fungicide was rotated with a FRAC code 11 fungicide on a weekly basis (Table 5). Percentage of orange fruit at harvest in 2007 was higher in cv. Magic Lantern at $98 \%$ compared with $79 \%$ in $\mathrm{cv}$. Howden.

\section{Conclusions}

Results suggest that practical resistance to FRAC code 3 and 11 fungicides developed in cucurbit powdery mildew affecting pumpkin during this study. Previous studies have used indirect methods of determining fungicide resistance development in the field where reduced control of the pathogen, based on previous field research and efficacy data, has been observed (McGrath, 2005). The ratings of the bottom surfaces of leaves suggest that cucurbit powdery mildew developed fungicide resistance to the FRAC code 11 fungicide in all 3 years of the study and that by Year 3 of the study, the efficacy of the FRAC code 3 fungicide was reduced. This is the first report of cucurbit powdery mildew developing practical resistance to FRAC code 3 and 11 fungicides in New Jersey.

Fungicide resistance development has the capability to develop regardless of cultivar resistance or tolerance to the pathogen. 
Table 3. Means of total number of harvested fruit, number of harvested orange fruit, total weight of orange fruit, average size (weight) of orange fruit, percent harvested orange fruit, and percentage of fruit with good stems by year and fungicide program.

\begin{tabular}{|c|c|c|c|c|c|c|}
\hline \multirow[b]{2}{*}{ Fungicide program } & \multicolumn{2}{|c|}{ Total number of } & \multicolumn{2}{|c|}{ Orange fruit wt $(\mathrm{kg})$} & \multicolumn{2}{|c|}{ Percent } \\
\hline & $\begin{array}{l}\text { Harvested } \\
\text { fruit }\end{array}$ & $\begin{array}{l}\text { Orange } \\
\text { fruit }\end{array}$ & Total & $\begin{array}{l}\text { Fruit } \\
\text { size }\end{array}$ & $\begin{array}{l}\text { Orange } \\
\text { fruit }\end{array}$ & $\begin{array}{l}\text { Good } \\
\text { stems }\end{array}$ \\
\hline & \multicolumn{6}{|c|}{2005} \\
\hline Protectants only & 27.0 & 21.3 & 64.6 & 3.1 & 78 & $67 b^{z}$ \\
\hline Standard program & 21.9 & 19.1 & 74.7 & 3.7 & 87 & $79 \mathrm{ab}$ \\
\hline Intensive program & 23.1 & 17.9 & 59.7 & 3.3 & 77 & $53 \mathrm{~d}$ \\
\hline FRAC group 3 weekly & 29.3 & 23.0 & 86.7 & 3.7 & 80 & $81 \mathrm{a}$ \\
\hline FRAC group 11 weekly & 29.1 & 25.8 & 91.7 & 3.5 & 89 & $65 \mathrm{bc}$ \\
\hline \multirow[t]{2}{*}{$P$ value } & NS & NS & NS & NS & NS & 0.01 \\
\hline & \multicolumn{6}{|c|}{2006} \\
\hline Protectants only & 21.0 & 15.8 & 69.1 & 4.5 & 74 & 95 \\
\hline Standard program & 22.1 & 19.0 & 93.9 & 5.0 & 86 & 93 \\
\hline Intensive program & 19.3 & 15.3 & 75.5 & 5.0 & 80 & 96 \\
\hline FRAC group 3 weekly & 22.6 & 16.5 & 94.4 & 5.3 & 79 & 98 \\
\hline FRAC group 11 weekly & 21.9 & 17.3 & 87.1 & 5.1 & 80 & 97 \\
\hline \multirow[t]{2}{*}{$P$ value } & NS & NS & NS & NS & NS & NS \\
\hline & \multicolumn{6}{|c|}{2007} \\
\hline Protectants only & 14.5 & 13.1 & $78.5 \mathrm{~b}$ & 6.3 & 89 & 68 \\
\hline Standard program & 13.0 & 11.4 & $73.0 \mathrm{~b}$ & 6.6 & 87 & 73 \\
\hline Intensive program & 14.2 & 12.8 & $85.5 \mathrm{ab}$ & 6.9 & 84 & 70 \\
\hline FRAC group 3 weekly & 14.5 & 13.4 & $113.6 \mathrm{a}$ & 8.7 & 86 & 84 \\
\hline FRAC group 11 weekly & 12.1 & 11.1 & $84.5 \mathrm{ab}$ & 7.3 & 88 & 81 \\
\hline$P$ value & NS & NS & 0.035 & NS & NS & NS \\
\hline Analysis of variance & \multicolumn{6}{|c|}{2005} \\
\hline Fungicide program (FP) & 0.0759 & 0.1304 & 0.0089 & 0.0174 & 0.2230 & 0.0022 \\
\hline Cultivar (CV) & 0.0139 & 0.5967 & $<0.0001$ & $<0.0001$ & 0.0001 & $<0.0001$ \\
\hline $\mathrm{FP} \times \mathrm{CV}$ & 0.9858 & 0.8743 & 0.3606 & 0.1154 & 0.3559 & 0.4473 \\
\hline $\begin{array}{l}\text { Fungicide application } \\
\text { (FA) }\end{array}$ & 0.0768 & 0.2402 & 0.0052 & 0.001 & 0.7426 & $<0.0001$ \\
\hline $\mathrm{FP} \times \mathrm{FA}$ & 0.3296 & 0.1715 & 0.0797 & 0.2439 & 0.7163 & 0.0101 \\
\hline $\mathrm{CV} \times \mathrm{FA}$ & 0.3726 & 0.0295 & 0.0074 & 0.4813 & 0.0437 & 0.4499 \\
\hline \multirow[t]{2}{*}{$\mathrm{FP} \times \mathrm{CV} \times \mathrm{FA}$} & 0.2707 & 0.3541 & 0.0693 & 0.1700 & 0.3308 & 0.1078 \\
\hline & \multicolumn{6}{|c|}{2006} \\
\hline Fungicide program (FP) & 0.8296 & 0.6701 & 0.1843 & 0.0659 & 0.2283 & 0.1316 \\
\hline Cultivar (CV) & 0.0001 & 0.0006 & 0.0164 & 0.0027 & 0.3773 & 0.2638 \\
\hline $\mathrm{FP} \times \mathrm{CV}$ & 0.4100 & 0.3372 & 0.2320 & 0.7417 & 0.9690 & 0.8130 \\
\hline $\begin{array}{l}\text { Fungicide application } \\
\text { (FA) }\end{array}$ & 0.0396 & 0.9189 & 0.0696 & 0.0186 & 0.0002 & $<0.0001$ \\
\hline $\mathrm{FP} \times \mathrm{FA}$ & 0.5360 & 0.4896 & 0.2884 & 0.5980 & 0.5351 & 0.3766 \\
\hline $\mathrm{CV} \times \mathrm{FA}$ & 0.5410 & 0.7395 & 0.9598 & 0.5938 & 0.9203 & 0.3328 \\
\hline \multirow[t]{2}{*}{$\mathrm{FP} \times \mathrm{CV} \times \mathrm{FA}$} & 0.3836 & 0.4415 & 0.6977 & 0.8911 & 0.9649 & 0.5008 \\
\hline & \multicolumn{6}{|c|}{2007} \\
\hline Fungicide program (FP) & 0.3997 & 0.2242 & 0.2216 & 0.0579 & 0.4473 & 0.1135 \\
\hline Cultivar (CV) & 0.0001 & 0.0001 & 0.0001 & 0.0510 & 0.0001 & 0.0001 \\
\hline $\mathrm{FP} \times \mathrm{CV}$ & 0.0898 & 0.0229 & 0.0114 & 0.1274 & 0.5220 & 0.2058 \\
\hline $\begin{array}{l}\text { Fungicide application } \\
\text { (FA) }\end{array}$ & 0.0001 & 0.0001 & 0.0001 & 0.0282 & 0.3481 & 0.0001 \\
\hline $\mathrm{FP} \times \mathrm{FA}$ & 0.6669 & 0.5013 & 0.0350 & 0.5585 & 0.3188 & 0.1265 \\
\hline $\mathrm{CV} \times \mathrm{FA}$ & 0.9826 & 0.6584 & 0.3038 & 0.7109 & 0.5953 & 0.0797 \\
\hline$\underline{\mathrm{FP}} \times \mathrm{CV} \times \mathrm{FA}$ & 0.9568 & 0.9635 & 0.9929 & 0.5898 & 0.2741 & 0.0848 \\
\hline
\end{tabular}

zMeans within a column with letters in common are not significantly different according to Tukey's honestly significant difference test $(\alpha=0.05)$.

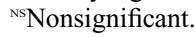

Table 4. Mean total number of orange fruit, total orange fruit weight, and percentage orange fruit from pumpkin cvs. Howden and Magic Lantern at harvest in 2005 by cultivar and fungicide application (sprayed or unsprayed).

\begin{tabular}{|c|c|c|c|c|c|c|}
\hline \multirow[b]{2}{*}{ Cultivar } & \multicolumn{2}{|c|}{$\begin{array}{l}\text { Total number } \\
\text { of orange fruit }\end{array}$} & \multicolumn{2}{|c|}{$\begin{array}{l}\text { Total orange } \\
\text { fruit wt }(\mathrm{kg})\end{array}$} & \multicolumn{2}{|c|}{$\begin{array}{l}\text { Percent orange } \\
\text { fruit }\end{array}$} \\
\hline & Fungicide & No fungicide & Fungicide & No fungicide & Fungicide & $\overline{\text { No fungicide }}$ \\
\hline Howden & 20 & 21 & $59 a^{z}$ & $58 \mathrm{a}$ & $72 \mathrm{a}$ & $77 \mathrm{a}$ \\
\hline Magic Lantern & 23 & 20 & $92 \mathrm{~b}$ & $75 \mathrm{~b}$ & $92 \mathrm{~b}$ & $89 \mathrm{~b}$ \\
\hline$P$ value & 0.0688 & NS & $<0.0001$ & 0.0005 & $<0.0001$ & 0.0012 \\
\hline
\end{tabular}

${ }^{\mathrm{z}}$ Means within a column followed by the same letter are not significantly different from each other using tests of simple main effect $(\alpha=0.05)$.

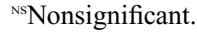

Table 5. Total weight (in $\mathrm{kg}$ ) of orange fruit in pumpkin cvs. Howden and Magic Lantern in 2007.

\begin{tabular}{lcc}
\hline Fungicide program & Howden & $\begin{array}{c}\text { Magic } \\
\text { Lantern }\end{array}$ \\
\hline Protectants only & 48.8 & $95.7 \mathrm{ab}^{\mathrm{z}}$ \\
Standard program & 57.7 & $65.7 \mathrm{~b}$ \\
Intensive program & 37.8 & $105.8 \mathrm{ab}$ \\
FRAC group 3 weekly & 47.4 & $120.7 \mathrm{a}$ \\
FRAC group 11 weekly & 35.0 & $116.6 \mathrm{a}$ \\
$P$ value & $\mathrm{NS}$ & 0.0025 \\
\hline
\end{tabular}

${ }^{\mathrm{z}}$ Means within a column with letters in common are not significantly different according to Tukey's honestly significant difference test $(\alpha=0.05)$.

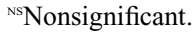

Research has also shown that chemical control can be more effective than genetic control on powdery mildew development in pumpkin (McGrath, 2001b). This research, and as suggested by McGrath, confirms fungicide-resistant powdery mildew populations may develop on the bottom side of leaves when effective protectant fungicides are used in season-long control programs. If such occurs, determining when high-risk fungicides are losing efficacy (i.e., when fungicide resistance is developing) in the field may be very difficult for growers to detect during the production season (McGrath, 2001a). Based on this information, and as suggested by McGrath, growers who improperly use high-risk fungicides such as FRAC code 3 and 11 fungicides may be selecting for resistant populations and putting other growers in the immediate region in danger of the developing resistant populations.

Understanding of FRAC codes by vegetable farmers is critically important for the proper management of economically important vegetable diseases and fungicide resistance development. In recent years, chemical manufacturers have made an effort to put FRAC codes on the front of fungicide container labels and include resistance management recommendations. More emphasis on training vegetable farmers to understand the importance of knowing FRAC codes and proper fungicide resistance management in vegetable production is needed. This is especially important in vegetable production: 1) where high-risk fungicides may be used to control a single pathogen on multiple crops; 2) where high-risk fungicides may be used to control multiple pathogens on multiple crops; and 3 ) where fungicide resistance is known to exist in economically important diseases such as cucurbit powdery mildew and downy mildew that are caused by pathogens that disseminate over vast geographic regions in the United States each year.

\section{Literature Cited}

Alexander, S.A. and C.M. Waldenmaier. 1999. Evaluation of fungicides for control of powdery mildew in pumpkin, 1998. Fungic. Nematic. Tests. 54:224.

Baumler, S. 2004. Development and evaluation of molecular diagnostic systems for QoI fungicide 
resistance in fungal phytopathogens. Technical University of Munich, Bavaria. Thesis.

Cohen, R., Y. Burger, and N. Katzir. 2004. Monitoring physiological races of Podosphaera xanthii (syn. Sphaerotheca fuliginea), the causal agent of powdery mildew in cucurbits: Factors affecting race identification and the importance for research and commerce. Phytoparasitica 32:174-183.

Crop profile for pumpkins in New Jersey. 2007. 28 Jan. 2008. <http://www.pestmanagement.rutgers. edu/njinpas/CropProfiles/pumpkinCP.pdf $>$.

Cushman, K.E., W.B. Evans, D.M. Ingram, P.D. Gerard, R.A. Straw, C.H. Canaday, J.E. Wyatt, and M.M. Kenty. 2007. Reduced foliar disease and increased yield of pumpkin regardless of management approach or fungicide combinations. Hort Technology 17:56-61.

Epinat, C., M. Pitrat, and F. Bertrand. 1992. Genetic analysis of resistance of five melon lines to powdery mildews. Euphytica $65: 135-144$.

Everts, K.L. 1999a. Integrated pumpkin disease management using a cover crop, host resistance and reduced fungicide application. Phytopathology 89:S25 [abstr.].

Everts, K.L. 1999b. First report of Benomyl resistance in Didymella bryoniae in Delaware and Maryland. Plant Dis. 83:304.

Everts, K.L. 2002. Reduced fungicide applications and host resistance for managing three diseases in pumpkin grown on a no-till cover crop. Plant Dis. 86:1134-1141.

Fitzgerald, C.B., K.L. Everts, and M.J. Newell. 2005. Evaluation of pumpkin cultivars under conventional and reduced risk fungicide programs, 2004. Biol. Cult. Tests Control Plant Dis. 20:V009.

Fungicide Resistance Action Committee. 2006. 28 Jan. $2008<$ http://www.frac.info/frac/index.htm $>$.

Huggenberger, F., M.A. Collins, and G. Skylakakis. 1984. Decreased sensitivity of Sphaerotheca fuliginea to fenarimol and other ergosterol-biosynthesis inhibitors. Crop Prot. 3:137-149.

James, R.V. and W.R. Stevenson. 2003. Evaluation of pumpkin and squash varieties for resistance to powdery mildew-Hancock, WI, 2002. Biol. Cult. Tests Control Plant Dis. 18:V002.

James, R.V. and W.R. Stevenson. 2004. Evaluation of pumpkin and squash varieties for resistance to powdery mildew-Hancock, WI, 2003. Biol. Cult. Tests Control Plant Dis. 19:V003.

James, R.V. and W.R. Stevenson. 2005. Evaluation of pumpkin and squash varieties for resistance to powdery mildew-Hancock, WI, 2004. Biol. Cult. Tests Control Plant Dis. 20:V005.

James, R.V. and W.R. Stevenson. 2006. Evaluation of pumpkin and squash varieties for resistance to powdery mildew-Hancock, WI, 2005. Biol. Cult. Tests Control Plant Dis. 21:V012.

Kendall, S.J. 1986. Cross-resistance of triadimenolresistant fungal isolates to other sterol C-14 demethylation inhibitor fungicides. Br. Crop Prot. Conf.-Pests Dis. 2:539-546.

Kooistra, E. 1968. Powdery mildew resistance in cucumber. Euphytica 17:236-244.

Kuck, K.H. and A. Mehl. 2003. Trifloxystrobin: Resistance risk and resistance management. Pflanzenschutz-Nachrichten Bayer 56:313325.

Littell, R.C., G.A. Milliken, W.W. Stroup, R.D. Wolfinger, and O. Schabenberger. 2006. SAS for mixed models. 2nd Ed. SAS Institute Inc., Cary, NC.

Louws, F.J. and J.G. Driver. 2001. Evaluation of pepper lines for resistance to Phytophthora crown and root rot and TSWV incidence, 2000. Biol. Cult. Tests Control Plant Dis. 18:V008.

Louws, F.J. and J.G. Driver. 2005. Evaluation of pepper lines for resistance to Phytophthora crown and root rot incidence, 2004. Biol. Cult. Tests Control Plant Dis. 20:V021.

McGrath, M.T. 1996a. Successful management of powdery mildew in pumpkin with disease threshold-based fungicide programs. Plant Dis. 80:910-916.

McGrath, M.T. 1996b. Increased Resistance to triadimefon and to benomyl in Sphaerotheca fuliginea populations following fungicide usage over one season. Plant Dis. 80:633639.

McGrath, M.T. 2001a. Fungicide resistance in cucurbit powdery mildew: Experiences and challenges. Plant Dis. 85:236-245.

McGrath, M.T. 2001b. Alternative fungicides to Bravo evaluated on pumpkin cultivars differing in susceptibility to powdery mildew, 2000. Fungic. Nematic. Tests. 56:V77.

McGrath, M.T. 2005. Occurrence of resistance to QoI, DMI, and MBC fungicides in Podosphaera xanthii in 2004 and implication for controlling cucurbit powdery mildew. Resistant Pest Management Newsletter. 14:36-40.

McGrath, M.T. and J.F. Davey. 2006. Comparison of powdery mildew resistant pumpkin under a reduced-fungicide program, 2005. Biol. Cult. Tests Control Plant Dis. 21:V021.

McGrath, M.T. and N. Shishkoff. 1999. Evaluation of biocompatible products for managing cucurbit powdery mildew. Crop Prot. 18:471-478.

McGrath, M.T. and N. Shishkoff. 2001. Resistance to triadimefon and benomyl: Dynamics and impact on managing cucurbit powdery mildew. Plant Dis. 85:147-154.
McGrath, M.T. and N. Shishkoff. 2003. First report of the cucurbit powdery mildew fungus (Podosphaera xanthii) resistant to strobilurin fungicides in the United States. Plant Dis. $87: 1007$.

McGrath, M.T. and H. Staniszewska. 1994. An IPM program for powdery mildew in pumpkin that includes timing of chemical control and fungicide resistance considerations. (abstr.). Phytopathology 84:545.

Mossler, M.A. and O.N. Nesheim. 2003. Florida crop/pest management profile: Squash. 28 Jan. 2008. <http://edis.ifas.ufl.edu/PI046>.

Norton, J.D. 1982. Gummy stem blight resistance in muskmelon. HortScience 17:477.

O'Brien, R.G. 1994. Fungicide resistance in populations of cucurbit powdery mildew (Sphaerotheca fuliginea). N.Z. J. Crop Hort. Sci. 22:145-149.

O’Brien, R.G., L.L. Vawdrey, and R.J. Glass. 1988. Fungicide resistance in cucurbit powdery mildew (Sphaerotheca fuliginea) and its effect on field control. Aust. J. Exp. Agr. 28:417423.

Ohtsuka, N., K. Sou, T. Amano, M. Ojima, Y. Nakazawa, and Y. Yamada. 1988. Decreased sensitivity of cucumber powdery mildew (Sphaerotheca fuliginea) to ergosterol biosynthesis inhibitors. Ann. Phytopathol. Soc. Jpn. 54:629-632.

Pernezny, K. and W.M. Stall. 2005. Powdery mildew of vegetables. Florida Cooperative Extension Service document PP-14. 29 Jan. 2008. <http://edis.ifas.ufl.edu/pdffiles/VH/ VH01400.pdf>.

Peterson, R.A. 1973. Field resistance to benomyl in cucurbit powdery mildew. Aust. Plant Pathol. Soc. Nwsl. 2:27-28.

Schroeder, W.T. and R. Provvidenti. 1969. Resistance to benomyl in powdery mildew of cucurbits. Plant Dis. Rep. 53:271-275.

Shamiyeh, N.B., R.A. Straw, C.A. Mullins, and R.A. Follum. 1999. Foliar fungicides for control of diseases on pumpkins, 1998. Fungic. Nematic. Tests 54:233-234.

U.S. Department of Agriculture. 2006. Vegetable 2005 Summary. 28 Jan. 2008. <http://usda. mannlib.cornell.edu/usda/nass/VegeSumm/2000s/ 2006/VegeSumm-01-27-2006.pdf>.

Van der Meer, Q.P., J.L. Van Bennekom, and A.C. Van der Giessen. 1978. Gummy stem blight resistance of cucumber (Cucumis sativus L.). Euphytica 27:861-864.

Zitter, T.A., D.L. Hopkins, and C.E. Thomas (eds.) 1996. Compendium of cucurbit diseases. The American Phytopathological Society, St. Paul, $\mathrm{MN}$. 